\title{
THE GENOTYPE OF HUMAN PAPILLOMA VIRUS OF MALE PATIENTS WITH ANOGENITAL WARTS
}

\author{
Dwi Murtiastutik ${ }^{1}$, Gondo Mastutik ${ }^{2}$, Alphania Rahniayu ${ }^{2}$, Afria Arista ${ }^{1}$, Trisniartami Setyaningrum ${ }^{1}$ \\ ${ }^{1}$ Department of Dermatology and Venereology, ${ }^{2}$ Department of Anatomic Pathology, Faculty of Medicine, Universitas \\ Airlangga, Dr. Soetomo Hospital, Surabaya, Indonesia
}

\section{ABSTRACT}

Human papillomavirus (HPV) infection is one of the most common sexually transmitted infections. HPV high risk (HPVHR) were HPV16,18 related with invasive penile carcinomas, and HPV low risk (HPVLR) were HPV6,11 related to anogenital warts. Male infection is usually asymptomatic that it would be explain increasing the incidence of HPV associated cancers. Identification HPV genotype is very important for predicting the development of the diseases, to be benign or malignant cancer. The objective of this study was to identify the genotype of HPV that infect men with anogential warts. This research used 12 biopsy specimens from men patient with anogenital warts at Outpatient clinic of Department Dermatology and Venereology, Dr. Soetomo General Hospital period 2016-2017. The specimens were diagnozed by pathologist and HPV gentoyping was done to detect 40 HPV genotype including HPVHR and HPVLR. The result showed that 58\% (7/12) were positive for HPVLR and 42\% (5/12) were positive for HPV LR/HR. The genotype HPV that infected men patient with anogenital warts is HPVLR $(H P V 6,11)$ and HPVHR $(H P V 18,51,52,82)$ with single infection of HPVLR or mutiple infection HPVLR/LR or HPVLR/HR. The infection of HPVHR would be develops to be malignant transformation. It suggested that HPV genotype needs to be checked the for the anogenital warts cases for predicting the development of the diseases.

Keywords: Genitals warts; Human Papilloma Virus; condyloma; penile carcinoma

\section{ABSTRAK}

Infeksi human papillomavirus (HPV) adalah salah satu infeksi menular seksual yang paling umum. HPV Risiko tinggi (HPV HR) adalah HPV16, 18 yang berhubungan dengan invasive penile carcinomas, dan HPV risiko rendah (HPVLR) adalah HPV6, 11 terkait dengan kutil anogenital. Infeksi pada laki-laki biasanya asimtomatik yang dapat menjelaskan peningkatan kejadian kanker terkait HPV. Identifikasi genotipe HPV sangat penting untuk memprediksi perkembangan penyakit, menjadi kanker jinak atau ganas. Tujuan dari penelitian ini adalah untuk mengidentifikasi genotipe HPV yang menginfeksi pria dengan kutil anogential. Penelitian ini menggunakan 12 spesimen biopsi dari pasien laki-laki dengan kutil anogenital di klinik Rawat Jalan Departemen Kesehatan Kulit dan Kelamin, Dr. Soetomo General Hospital periode 2016-2017. Spesimen didiagnosis oleh ahli patologi dan HPV gentoyping dilakukan untuk mendeteksi genotipe 40 HPV termasuk HPVHR dan HPVLR. Hasilnya menunjukkan bahwa 58\% (7/12) adalah positif HPVLR dan 42\% (5/12) adalah positif HPV LR/HR. Genotipe HPV yang menginfeksi pria yang menderita kutil anogenital adalah HPVLR (HPV6,11) dan HPVHR (HPV18,51,52,82) dengan infeksi tunggal HPVLR atau infeksi mutiple HPVLR/LR atau HPVLR/HR. Infeksi HPVHR akan berkembang menjadi transformasi malignant. Ini menunjukkan bahwa perlu memeriksa genotipe HPV untuk kasus kutil anogenital untuk memprediksi perkembangan penyakit.

Kata kunci: Kutil anogenital; Human Papilloma Virus; condyloma; penile carcinoma

Correspondence: Gondo Mastutik, Department of Anatomic Pathology, Faculty of Medicine, Universitas Airlangga, J1. Prof Dr Moestopo 47, Surabaya 60131, phone. 62-31-5020251, ext 151, e-mail: gondomastutik@fk.unair.ac.id, gondomastutik@gmail.com

pISSN:2355-8393 • eISSN: 2599-056x • doi: http://dx.doi.org/10.20473/fmi.v55i2.14334

- Fol Med Indones. 2019;55:100-106 • Received 29 Mar 2018 • Accepted 20 Sep 2018

- Open access under CC-BY-NC-SA license • Available at https://e-journal.unair.ac.id/FMI/

\section{INTRODUCTION}

Human papilloma virus (HPV) infection is one of the most common sexually transmitted infections. It is known that up to $70 \%$ of both men and women of the world population will be infected during their lifetime
(Daugherty and Byler 2017; Nielson et al. 2007). This infection associated with the development of genital warts, penile intraepithelial neoplasia, and invasive penile carcinomas. These HPV low risk (HPV LR) findings at genital condyloma, anal warts, and adult or juvenile papillomatosis, which are directly attributable 
to subtypes HPV 6 and HPV 11. Genital warts are the most common clinical manifestation of HPV in men. Though they are benign and not associated with mortality, they are a source of psychosocial distress and physical discomfort. HPV infection can also develop into invasive penile carcinoma which is associated with morbidity and mortality. Approximately $40 \%$ of invasive penile carcinomas are attributable to HPV high risk (HPV HR) with HPV 16, 18, and 6/11 being the genotypes most commonly detected in penile tumors. Penile carcinomas of the basaloid and warty histologic subtypes are most likely to test positive for HPV (Daugherty and Byler 2017; Anic and Giuliano 2011).

Anogenital warts are a worldwide public health problem. They consist of epithelial proliferations caused by HPV, whose transmission occurs mainly through sexual intercourse. Most patients (81\%) presented mild or no impairment of quality of life. The main dimensions affected were sex life, symptoms, and embarrassment. The low impact on quality of life may well justify the delay in seeking medical treatment, favoring the spread of the disease. The disease causes embarrassment and limitations, especially when the genitals are exposed, such as during sexual intercourse, and even more when having sex with multiple partners. The therapeutic options for anogenital warts are, in most cases, of surgical nature, causing the need for care and pain/discomfort, especially for those who require many sessions. Such evidence suggests that the availability of treatments of less morbidity may well be important in convincing the patients to seek early treatment and the interruption of the transmission chain (de Carmargo et al. 2017).

The carcinogenesis of penile cancer is thought to involve two pathways, one related to inflammation and other dermatological conditions of the penis, and other related to HPV infection. About one-third to one-quarter of invasive penile cancers may be related to HR-HPV according to retrospective studies. Male infection is usually asymptomatic, and this could explain why the incidence of HR-HPV associated cancers and precancerous lesions are now increasing (Nielson et al. 2007). Identification HPV genotype is very important to do for predicting the development of the diseases, to be condyloma or invaseive penile cancer. The objective of this study was to identify the genotype of HPV that infect men with anogential warts.

\section{MATERIALS AND METHODS}

This was the descriptive observasional research with cross sectional approach to obtain the data of HPV genotypes that infected the patient of condyloma acuminata in men. This research was conducted at Outpatient clinic of Department Dermatology and Venereology, Dr. Soetomo General Hospital period 2016-2017. This research used 12 biopsy specimens from patient with anogenital warts in men. The specimens were divided to be 2 section, the first section then processed become formalin fix paraffin embedded (FFPE) and continued with Hematoxylin Eosin (HE) staining for histopathology diagnosed by Pathologist. The second section then used as specimen for HPV genotyping examinations. This study was done after approving the etical research from Dr. Soetomo General Hospital Surabaya.

DNA virus was extracted from biopsy tissue of condyloma acuminata by using QIAamp DNA Mini Kit (Qiagen) according to the manufacture's protocol and genotyping was performed to detect HPV DNA, using Ampliquality HPV type express v 3.0 (AB Analitica) which detect 40 HPV genotype classified as high risk or low risk, depending on their association with development of carcinoma. It allows identification of HPV genotypes: $6,11,16,18,26,31,33,35,39,40,42$, $43,44,45,51,52,53,54,55,56,58,59,61,62,64,66$, 67, 68a, 68b, 69, 70, 71, 72, 73, 81, 82, 83,84, 87, 89, 90.

\section{RESULTS}

\section{Characteristics of Patient}

Patients in this study consisted of 12 men who aged 1964 years old. The age of most patients was under 34 yeras old. Sexual orientations of men who involved in this study were heterosexuals, homosexuals, and bisexuals (Tabel 1).

Clinical characteristic of patients consisted of histofy of lession, duration sympthom, type theraphy, effloresence form, and location of lession. The history of anogenital lession for first lession were 7/12 (58\%), and for recurrence lession were $5 / 12(42 \%)$. The duration of lession for $<3$ months were 5/12 (42\%), 4-6 months were $6 / 12(50 \%)$, and for 1 year were $1 / 12$ $(8 \%)$. The type therapy of patients for TCA and cauterization were $6 / 12(50 \%)$. The most efflorecence type of anogenital lession were papula that were 10/12 $(83 \%)$. The location of lession were penile and anus. The most lession were located at penis (7/12) and anus were 4/12. The location of anogenital lession at bisexuals were located at anus (Table 1). 
Table 1. Characteristics of patients with anogenital warts in men

\begin{tabular}{|c|c|c|}
\hline Characteristics of Patients & $\begin{array}{c}\text { Total } \\
\text { (persons) }\end{array}$ & Persentage \\
\hline \multicolumn{3}{|l|}{ Age } \\
\hline - $18-30$ & 10 & $83 \%$ \\
\hline - $\quad 31-44$ & 0 & $0 \%$ \\
\hline - $45-54$ & 1 & $8 \%$ \\
\hline - $55-54$ & 1 & $8 \%$ \\
\hline \multicolumn{3}{|l|}{ Sexual Partner } \\
\hline - Heterosexual (men having sex with women) & 9 & $75 \%$ \\
\hline - Homosexual (men having sex with men) & 1 & $8 \%$ \\
\hline - Bisexual (men having sex with men and women) & 2 & $17 \%$ \\
\hline \multicolumn{3}{|l|}{ The history of lesion } \\
\hline - First lesion & 7 & $58 \%$ \\
\hline - Recurrence lesion & 5 & $42 \%$ \\
\hline \multicolumn{3}{|l|}{ Duration sympthom } \\
\hline - 1 month & 2 & $17 \%$ \\
\hline - 2 month & 1 & $8 \%$ \\
\hline - 3 month & 2 & $17 \%$ \\
\hline - 4 month & 1 & $8 \%$ \\
\hline - 5 month & 2 & $17 \%$ \\
\hline - 6 month & 3 & $25 \%$ \\
\hline - 1 year & 1 & $8 \%$ \\
\hline \multicolumn{3}{|l|}{ Type Therapy } \\
\hline - TCA & 6 & $50 \%$ \\
\hline - Cauter & 6 & $50 \%$ \\
\hline \multicolumn{3}{|l|}{ Effloresence form } \\
\hline - Papula & 10 & $83 \%$ \\
\hline - $\quad$ Papul form chicken comb & 1 & $8 \%$ \\
\hline - Cauliflower & 1 & $8 \%$ \\
\hline \multicolumn{3}{|l|}{ Location of lession } \\
\hline - Penile & 7 & $58 \%$ \\
\hline - Anus & 4 & $33 \%$ \\
\hline - $\quad$ Penile and Anus & 1 & $8 \%$ \\
\hline
\end{tabular}

\section{Histopathologist diagnoses}

The result of histopathologis diagnoses showed that all of the sampel diagnosed as condyloma, some showed with focus dysplasia and koilocytosis (Fig. 1). Warty carcinoma (condylomatous) is characterized by an exophytic papillary growth, accompanied by significant fibrovascular cores and koilocytosis. This type is also different from papillary carcinoma and verrucous carcinoma. The warty carcinomas showed less lymphatic embolization, lymph node metastasis, and tumor infiltration of the corpus spongiosum and corpus cavernosum. There was no mortality in this group of patients, and these are most commonly associated with HPV infection (Guimarães et al. 2011).

\section{The genotype of HPV at anogenital warts lesion men}

The type of HPV in this research was determined using kit for rapid screening and genotyping of Human Papillomavirus by Single-Step PCR and Reverse Line
Blot. The result showed that from 12 male patient with genital warts, $7 / 12$ persons $(58 \%)$ positive infected HPV LR and $5 / 12$ persons $(42 \%)$ positive infected by multiple infection HPV LR/ HR. The genotypes of HPV LR were HPV 6, 11 and HPV HR were HPV 18, 51, 52, 82. The single infections were by HPV $6(1 / 12)$ persons and HPV $11(5 / 12)$ persons. The multiple infection by HPV LR were HPV 6/11 and the multiple infection by HPV LR and HPV HR were HPV 11/18, HPV 11/51, HPV 11/52/54, and HPV 11/82 (Table 2).

\section{DISCUSSION}

\section{Characteristics of Patient}

Genital warts are caused by human papillomavirus (HPV) that leading cause of anogenital malignancies (Kofoed et al. 2014). The incidence of extra genital warts was 2.8 cases $/ 100$ persons per year for condyloma and 0.2 cases $/ 100$ persons per years for penile intraepithelial neoplasia (Ingles et al. 2015). 
A

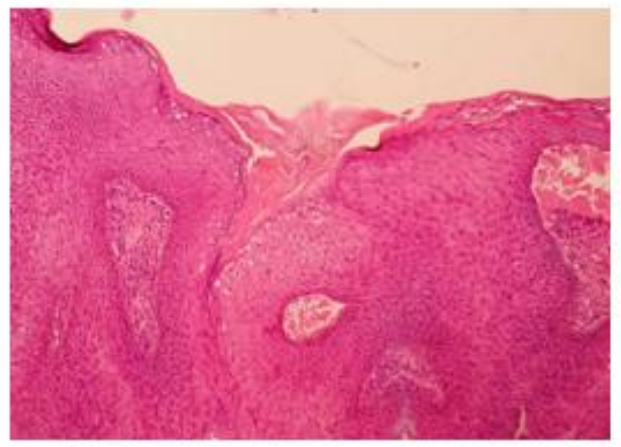

B

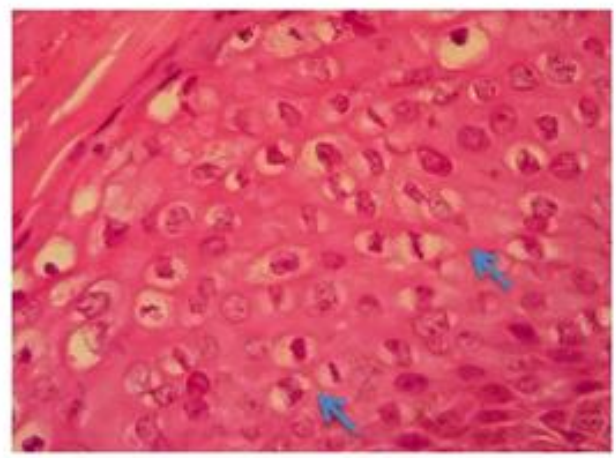

Fig. 1. Histopathology of condyloma with hematoxylin eosin (HE) staining, Condyloma at specimen that infected by HPV 11, 40x (A); arrow shows the koilocytosis apperance, 400x (B).

Table 2. The genotype HPV of Single and multiple infection in anogenital warts

\begin{tabular}{lccc}
\hline Genotype HPV & HR/LR & Total (persons) & Percentage (\%) \\
\hline HPV 6 & LR & 1 & $8,3 \%$ \\
HPV 6,11 & LR & 1 & $8,3 \%$ \\
HPV 11 & LR & 5 & $41.7 \%$ \\
HPV 11, 18 & LR/HR & 1 & $8,3 \%$ \\
HPV 11,51 & LR/HR & 1 & $8,3 \%$ \\
HPV 11,52,54 & LR/HR/LR & 1 & $8,3 \%$ \\
HPV 11,82 & LR/HR & 2 & $16.7 \%$ \\
\hline Total & & 12 & $99.9 \%$ \\
\hline
\end{tabular}

The incidence of genital warts is highest among men younger than age 30 years and significantly decreases with age (Anic et al. 2011). This is consistent with the results of this study ie the age of patients with genital warts in this study most at the age of 18-30 years (Table 1). These results are also consistent with cohort studies to follow extra genital lesion biopsy ( $\mathrm{n}=2754 \mathrm{men})$. The result showed that the cumulative incidence of extra genital lesion, including condyloma and penile intraepithelial neoplasia was highest among men $<45$ years old. In this study, younger men $(<45$ years old $)$ had the highest risk of developing an extra genital lesion (Ingles et al. 2015).

Sexual partner the patients in this research were consist of heterosexuals (men having sex with women), homosexuals (men having sex with men), and bisexsuals (men having sex with men and women). The result showed that $9 / 12$ persons $(75 \%)$ were heterosexuals, $1 / 12$ persons ( $8 \%$ ) was homosexuals, and $2 / 12$ persons $(17 \%)$ were bisexuals. The genotype HPV of heterosexuals was single infection HPV LR (HPV 11) and multiple infection HPV LR/LR (HPV 6/11) and HPV HR/LR (HPV 11/51, HPV 11/52/54, HPV 11/82). The genotype of homosexuals was HPV LR (HPV 6), and bisexuals were multiple infections HPV HR/LR (HPV 11/18 and HPV 11/82). The genital HPV prevalence was typically higher among bisexuals than among homosexuals or heterosexuals for groups of HPV genotypes including nononcogenic types (51\%, $36 \%$, and $42 \%$, respectively), and multiple types (37\%, $24 \%$, and $29 \%$, respectively). Prevalence of genital HPV may be higher among bisexuals than among heterosexuals and homosexuals (Nyitray et al. 2011).

The history of lesion showed that first lesion were $7 / 5$ persons $(58 \%)$ and recurrence lesion were $5 / 12$ persons (42\%). The genotype of HPV from the patients with recurrence lesion were single infection HPV LR (HPV 11 were 2 persons), multiple infection HPV LR/LR (HPV 6/11were 1 person) and multiple infections HPV LR/HR (HPV 11/82 were 2 persons). This recurrence lesion may be due to the latent and persistent infection HPV HR or LR who did not obtain the therapy properly.

The symptoms duration of the genital warts in this study $<3$ months were $42 \%$ (5/12), 4-6 months were 50\% $(6 / 12)$, and 1 year were $8 \%(1 / 12)$. This is probably due the awareness of patients to check into the clinic as soon as possible is still low so that there are patients who have checked out after symptoms appear one year.

The majority of HPV infections are asymptomatic with an estimated $70 \%$ of incident infections clearing within 
1 year. If an infection does not clear however it can progress to disease. Anogenital warts are the most common clinical manifestation of HPV infections. Though they are benign and not associated with mortality, they are a source of psychosocial distress and can cause physical discomfort including pain, bleeding and itching (Anic et al. 2011).

Genital warts are highly infectious and approximately $65 \%$ of people whose sexual partner has genital warts will develop warts. The estimated incubation period from HPV infection to genital wart development is 2 weeks to 8 months, with the majority of genital warts appearing 2-3 months after HPV infection. Approximately $20-30 \%$ of genital warts will regress spontaneously, however, the recurrence of warts is common (Anic et al. 2011).

Patients with genital warts in this study received TCA or cauterization therapy. TCA therapy is given to the patient if the lesion is papule with in size small. If the lesions are large, then proper therapy is cauterization therapy. In this reseach, 50\% patiens received TCA therapy dan also $50 \%$ received cauterization therapy. Most of the efflorence form in this study were papules as much as $10 / 12(83 \%)$, then papule in the form of a chicken jaw as much as $1 / 12(8 \%)$, and cauli flower form as much as $1 / 12(8 \%)$.

The location of genital warts in this study in men were in the penis and anus. Most of the lesions showed that in the penis were 7 people $(21.1 \%)$ and the anus were 4 people $(12.1 \%)$, and in the penis and anus simultaneously at 1 person $(3.0 \%)$. This result consistent with the research of Aubin et al (2008) the data showed that the penis $(42 \%)$ and perianal region (37\%) were the most frequent sites of genital warts (Aubin et al 2008).

\section{The genotype of HPV at anogenital warts lesion men}

Based on the report of the International Agency for Research on Cancer (IARC) about the human carcinogens, it was classified in 4 groups. The HPV types $16,18,31,33,35,39,45,51,52,56,58$, and 59 were classified as group 1, carcinogenic to humans. They all belong to the family of the a-Papillomaviridae, in particular to the species a5 (HPV51), a6 (HPV56), a7 (HPV18, HPV39, HPV45, HPV59) and a9 (HPV16, HPV31, HPV33, HPV35, HPV52, HPV58). The HPV 68 (a7) was belongs to group 2A that probably carcinogenic to human with limited evidence in humans and strong mechanistic evidence. HPV 26, 53, 66, 67, $70,73,82$ that classified as group 2B that possibly carcinogenic with limited evidence in humans for cervical cancer and the HPV 30, 34, 69, 85, 97 were also classified group $2 \mathrm{~B}$, that phylogenetic analogy to HPV types with sufficient or limited evidence in humans. Group 3 which belong to the alpha-10 species (HPV 6, 11), were not classifiable as to its carcinogenicity to humans, on the basis of inadequate epidemiological evidence and absence of carcinogenic potential in mechanistic studies (Bouvard et al. 2009; Arbyn et al 2014).

This study detect 40 HPV genotype: $6,11,16,18,26$, $31,33,35,39,40,42,43,44,45,51,52,53,54,55,56$, 58, 59,61, 62, 64, 66, 67, 68a, 68b, 69, 70, 71, 72, 73, 81, 82, 83,84, 87, 89, 90. HPV high risk (HPV HR) were HPV 16, 18, 26, 31, 33,35, 39, 45, 51, 52, 53, 55, 56, 58, 59, 66, 67, 68 (68a, 68b), 69, 73, 82. HPV low risk (HPV LR) were HPV 6, 11, 40, 42, 43, 44, 54, 61, $62,64,70,71,72,81,83,84,87,89,90$. The result from 12 male patient with genital warts showed that $7 / 12$ persons $(58 \%)$ positive infected HPV LR and 5/12 persons $(42 \%)$ positive infected by multiple infection HPV LR/ HR.

A total of 1,757 men had information regarding HPV DNA. Fifty-three men tested positive for HPV 6 or HPV 11 DNA. This corresponds to an estimated prevalence of $2.9 \%$ (95\% CI 2.2-3.8) of men aged $18-59$ years. In addition, $2.2 \%$ (95\% CI 1.5-3.3) of men reported a history of genital wart infection. There was no significant association with genital HPV DNA detection with age. Increasing number of sexual partners was associated with higher rates of both genital warts and HPV 6 and HPV 11 DNA (Daugherty M and Byler M, 2017).

The estimated prevalence of genital HPV DNA in the US male population is $2.9 \%$. This burden of disease could potentially be lowered with increased usage of quadrivalent and nonavalent vaccinations (Daugherty $\mathrm{M}$ and Byler M, 2017).

The genotype of HPV LR was HPV 6, 11 and HPV HR was HPV 18, 51, 52, 82. The prevalence of HR-HPV infection in men was $45.1 \%(79 / 175)$. Genital warts were observed in $10.3 \%(18 / 175)$ of the subjects (Lopez-Diez et al. 2017a). The prevalence of HPV HR infection in males was $50.4 \%$ (63/125). HPV $16 / 53 / 52 / 51 / 66 / 31$ were the most frequent genotypes (24/10.4/9.6/8.8/8/7.2\%, respectively). Among 60 infected couples, $62 \%$ shared at least one genotype: $41.7 \%$ couples were concordantly HPV16 positive and $18.3 \%$ were HPV16 negative (kappa value: 0.21 ). The proportion of women with the same genotype as their male partner was higher than the proportion of men sharing the same genotype as their female partner: $58.7 \%(37 / 63)$ vs $30.8 \%$ (37/120), p<0.0001 (LopezDiez et al. 2017b). 
The identification of HPV genotype is very important to know the progress of the diseasess, it would develop to be genital warts, penile intraepithelial neoplasia or invasive penile carcinomas. According to Anic and Giuliano (2011) infection HPV is one of the risk factor of development for penile cancer. The other risk factors that are most strongly associated with penile cancer are lack of neonatal circumcision, phimosis (the inability of uncircumcised men to fully retract the foreskin), anogenital warts. Circumcision most likely protects against penile cancer by reducing the risk of HPV acquisition, however, the timing of circumcision may infiuence the protective effect. Men circumcised after the neonatal period have a higher risk of penile cancer compared men who were circumcised at birth. Delayed circumcision may not be protective because men who are circumcised later in life often undergo the procedure as treatment for phimosis or an existing chronic inflammatory condition. Other risk factors for penile cancer include current smoking, early age at first sexual intercourse, high lifetime number of female sexual partners, lack of condom use, chronic inflammatory conditions including balantitis and lichen sclerosus, and treatment with ultraviolet photochemotherapy for psoriasis (Anic and Giuliano 2011). Therefore for avoiding this diseases was by the avoiding almost all of the risk factors except the circumcision at neonatal.

The other way to protect the HPV infection is by the vaccination. The potential role of HPV vaccination in men at risk of HPV infection is an important societal and health consideration. Unlike cervical cancer, penile cancer has no established screening or prevention program used in general clinical practice. Primary prevention of precursor penile neoplastic lesions is feasible with the implementation of prophylactic HPV vaccination programs (Flaherty et al. 2014). Male vaccination with the quadrivalent $\mathrm{HPV}$ vaccine that protects against HPV 6/11/16/18 has been shown to significantly reduce HPV-associated anogenital infection and disease in men. If the quadrivalent vaccine is successfully disseminated to large segments of the young male population, there is the potential for substantial reduction in genital HPV infection and related lesions in men (Anic \& Giuliano 2011).

\section{CONCLUSION}

The genotype HPV that infected men patient with anogenital warts is HPV LR and HPV HR. The genotype of HPV LR were HPV 6, 11 and HPV HR were HPV 18, 51, 52, 82, with single infection of HPV LR or mutiple infection HPV LR/LR or HPV LR/HR. There is an infection with HPV HR that it would be develop in transformation of malignant. It suggest that it need to check the HPV genotype for the anogenital warts cases to prdictic the development of the diseases.

\section{ACKNOWLEDGMENT}

Thank you for Indonesia Government in general, specially Faculty of Medicine Airlangga University for supporting this study by the university operational funding fiscal years at 2017.

\section{REFERENCES}

Anic GM, Giuliano AR (2011). Genital HPV infection and related lesions in men. Prev Med 53, S36-41

Arbyn M, Tommasino M, Depuydt C, Dillner J (2014). Are 20 human papillomavirus types causing cervical cancer? J Pathol 234, 431-5

Aubin F, Prétet JL, Jacquard AC, Saunier M, Carcopino X, Jaroud F, Pradat P, Soubeyrand B, Leocmach Y, Mougin C, Riethmuller D; EDiTH Study Group (2008). Human papillomavirus genotype distribution in external acuminata condylomata: a Large French National Study (EDiTH IV). Clin Infect Dis 47, 610-5

Bouvard V, Baan R, Straif K, Grosse Y, Secretan B, El Ghissassi F, Benbrahim-Tallaa L, Guha N, Freeman C, Galichet L, Cogliano V; WHO International Agency for Research on Cancer Monograph Working Group (2009). A review of human carcinogens--Part B: biological agents. Lancet Oncol 10, 321-2

Daugherty M, Byler T (2017). Genital wart and HPV prevalence in males in the United States from Penile Swabs: Results from NHANES. Sex Transm Dis 2017 Nov 16. doi: 10.1097/OLQ.0000000000000761

de Camargo CC, D'Elia MPB, Miot HA (2017). Quality of life in men diagnosed with anogenital warts. An Bras Dermatol 92, 427-429

Flaherty A, Kim T, Giuliano A, Magliocco A, Hakky TS, Pagliaro LC, Spiess PE (2014). Implications for human papillomavirus in penile cancer. Urol Oncol 32, 53.e1-8

Giuliano AR, Lazcano E, Villa LL, Flores R, Salmeron J, Lee JH, Papenfuss M, Abrahamsen M, Baggio ML, Silva R, Quiterio M (2009). Circumcision and sexual behavior: Factors independently associated with human papillomavirus detection among men in the HIM study. Int J Cancer 124, 1251-7

Guimarães GC, Rocha RM, Zequi SC, Cunha IW, Soares FA (2011). Penile cancer: epidemiology and treatment. Curr Oncol Rep 13, 231-9

Ingles DJ, Pierce Campbell CM, Messina JA, Stoler MH, Lin HY, Fulp WJ, Abrahamsen M, Sirak BA, O'Keefe MT, Papenfuss M, Gage C, Carvalho da Silva R, Gonzalez Sosa R, Rojas Juarez O, Villa LL, Lazcano Ponce E, Giuliano AR (2015). Human 
papillomavirus virus (HPV) genotype- and agespecific analyses of external genital lesions among men in the HPV Infection in Men (HIM) Study. J Infect Dis 211, 1060-7

Kofoed K, Sand C, Forslund O, Madsen K. (2014) Prevalence of human papillomavirus in anal and oral sites among patients with genital warts. Acta Derm Venereol 94, 207-11. doi: 10.2340/00015555-1718.

aLopez-Diez E, Perez S, Carballo M, Iñarrea A, de la Orden A, Castro M, Rodríguez M, Almuster S, Montero R, Perez M, Sanchez J, Ojea A. (2017) Lifestyle factors and oncogenic papillomavirus infection in a high-risk male population. PLoS One. 12(9):e0184492. doi: 10.1371/journal.pone.0184492. eCollection 2017.

bLópez Diez E, Pérez S, Iñarrea A, de la Orden A, Castro M, Almuster S, Tortolero L, Rodríguez M, Montero R, Ojea A. (2017) Prevalence and concordance of high-risk papillomavirus infection in male sexual partners of women diagnosed with high grade cervical lesions. Enferm Infecc Microbiol Clin. 35(5):273-277. doi: 10.1016/j.eimc.2016.02.014. Epub 2016 Mar 20

Nielson CM, Harris RB, Dunne EF, Abrahamsen M, Papenfuss MR, Flores R, Markowitz LE, Giuliano AR (2007). Risk factors for anogenital human papillomavirus infection in men. J Infect Dis 2007 Oct $15,1137-45$

Nyitray AG, da Silva RJ, Baggio ML, Lu B, Smith D, Abrahamsen M, Papenfuss M, Quiterio M, Villa LL, Giuliano AR (2011). The prevalence of genital HPV and factors associated with oncogenic HPV among men having sex with men and men having sex with women and men: the HIM study. Sex Transm Dis 38, 932-40 